\title{
Parapharyngeal Abscess
}

National Cancer Institute

\section{Source}

National Cancer Institute. Parapharyngeal Abscess. NCI Thesaurus. Code C128323.

An abscess that develops in the soft tissues of the lateral pharyngeal space. 